\title{
The Politics Today companion to
}
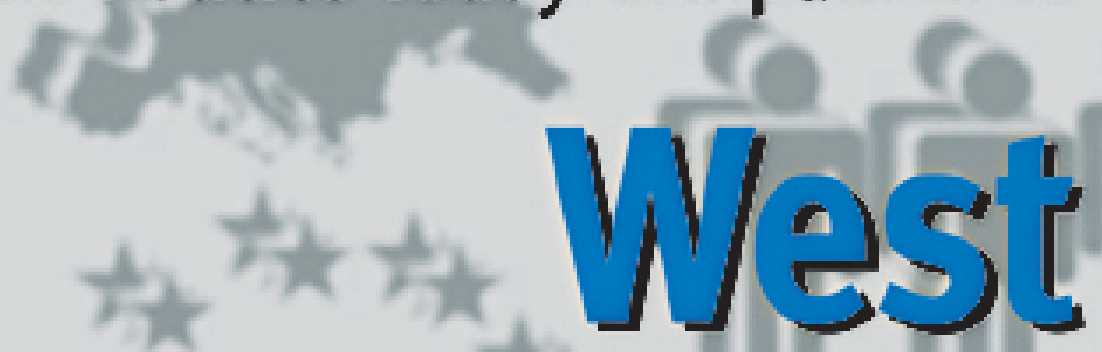

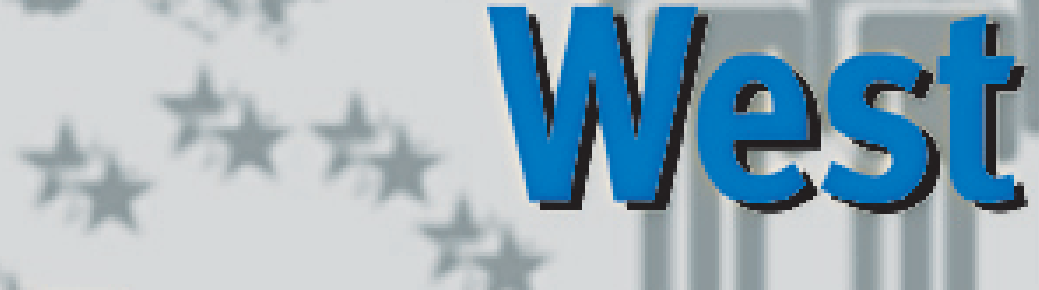
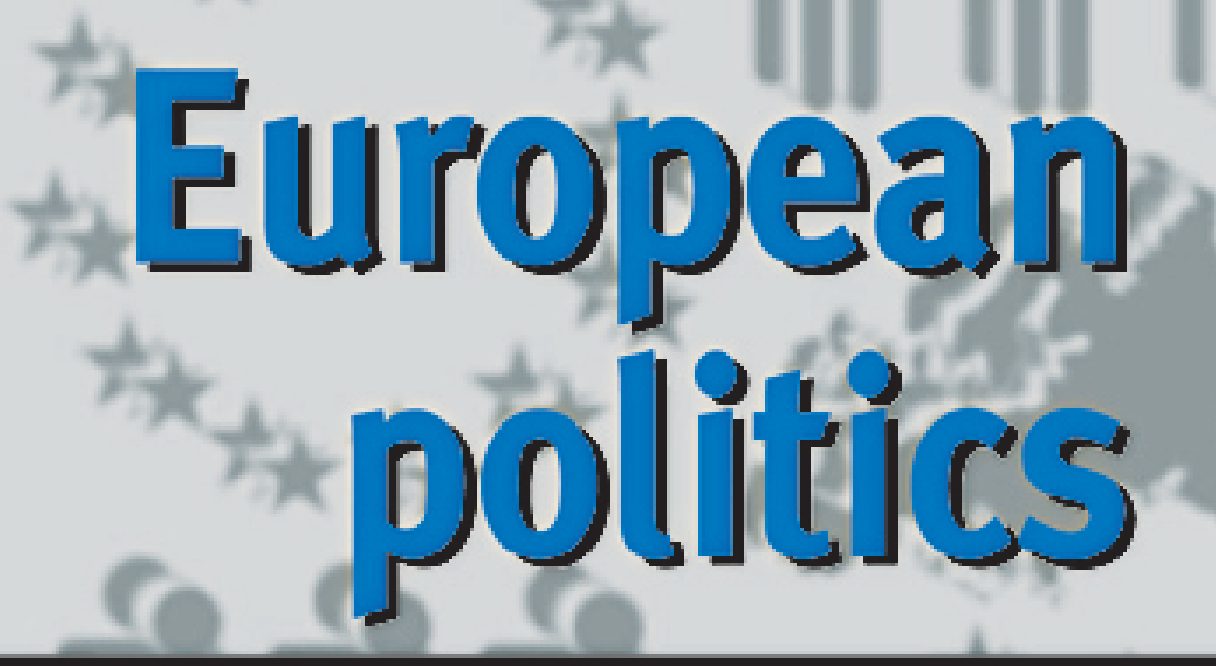

事

Geofirey R. Roberts and

东

\section{Patricia Hlogwood}

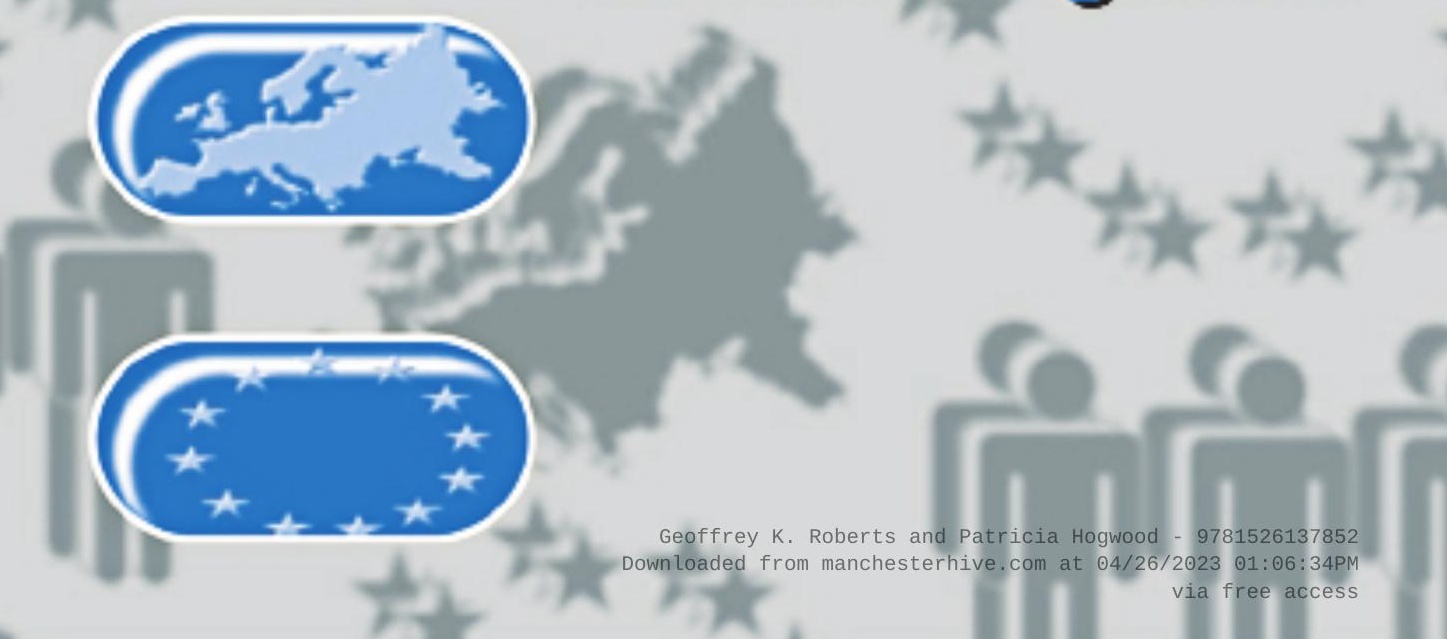




\section{THE POLITICS TODAY COMPANION TO WEST EUROPEAN POLITICS}

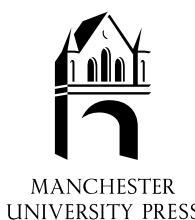


Ideology and politics in Britain today Ian Adams

Political ideology, 2nd edition Ian Adams

Scandinavian politics today David Arter

American society today Edward Ashbee

US politics today Edward Ashbee and Nigel Ashford

Pressure groups today Rob Baggot

French politics today, new edition David S. Bell

Local government today, 3rd edition J. A. Chandler

Political issues in Ireland today, 2nd edition Neil Collins (editor)

Irish politics today, 4th edition Neil Collins and Terry Cradden

General Elections today, 2nd edition Frank Conley

East Central European politics today Keith Crawford

US elections today (Elections USA, 2nd edition)

Philip John Davies

Political issues in America today Philip John Davies and Fredric A. Waldstein (editors)

British political parties today, 2nd edition Robert Garner and Richard Kelly

Spanish politics today John Gibbons
The Politics Today companion to American government

Alan Grant and Edward Ashbee

Political issues in Britain today, 5th edition Bill Jones (editor)

British politics today, 6th edition Bill Jones and Dennis Kavanagh

Trade unions in Britain today, 2nd edition John McIlroy

Italian politics today Hilary Partridge

Britain in the European Union today, 2nd edition

Colin Pilkington

The Civil Service in Britain today

Colin Pilkington

Devolution in Britain today Colin Pilkington

The Politics Today companion to the British Constitution

Colin Pilkington

Representative democracy in Britain today Colin Pilkington

German politics today

Geoffrey Roberts

European politics today Geoffrey Roberts and Patricia Hogwood

Debates in British politics today Lynton Robins and Bill Jones (editors)

Government and the economy today Graham P. Thomas

Prime Minister and Cabinet today Graham P. Thomas

Political communication today Duncan Watts 


\section{THE POLITICS TODAY COMPANION TO WEST EUROPEAN POLITICS}

Geoffrey K. Roberts

and Patricia Hogwood

Manchester University Press

Manchester 


\section{Copyright (c) Geoffrey K. Roberts and Patricia Hogwood 2003}

The right of Geoffrey K. Roberts and Patricia Hogwood to be identified as the authors of this work has been asserted by them in accordance with the Copyright, Designs and Patents Act 1988.

Published by Manchester University Press

Altrincham Street, Manchester M1 7JA, UK

www.manchesteruniversitypress.co.uk

British Library Cataloguing-in-Publication Data

A catalogue record for this book is available from the British Library

\section{Library of Congress Cataloging-in-Publication Data applied for}

ISBN 0719054206 hardback

0719054214 paperback

First published 2003

$1009080706050403 \quad 10987654321$

The publisher has no responsibility for the persistence or accuracy of URLs for any external or third-party internet websites referred to in this book, and does not guarantee that any content on such websites is, or will remain, accurate or appropriate.

Typeset by Carnegie Publishing Ltd, Lancaster 